\title{
Digitalization of Economy as the Economic Growth and Unemployment Risk Decrease Factor
}

\author{
Mirgorodskaya M.G. ${ }^{1}$ Rustamova I.T. ${ }^{2}$ Grachev S.A. ${ }^{3, *}$
}

\author{
${ }^{1}$ Moscow State University of Technology and Management named after K.G. Razumovsky (PKU), Moscow, Russia \\ ${ }^{2}$ Russian University of Transport, Moscow, Russia \\ ${ }^{3}$ Vladimir State University named after Alexander Grigoryevich and Nikolai Grigoryevich Stoletov, Vladimir, Russia \\ *Corresponding author. Email: grachev-sa@yandex.ru
}

\begin{abstract}
The digitalization process is the subject of research both for national and foreign researchers. The papers specified describe and analyze both the economic and social aspects of this process. A slightly limited number of papers by Russian authors is dedicated to this subject. The practical application of the results obtained is complicated due to the line of objective factors. A hypothesis of this study is an assumption of a close relationship between the national economic system's digital development and the result of its functioning, together with the unemployment parameters in terms of education existing. The objective of this study is to form a model of interconnection between the categories specified. The methodical base was formed by grouping, analysis and synthesis methods, and the regression analysis. The approach offered is based on objective data of the official statistics.

Initial data were divided into four categories, each of which reflects the individual features of the separate areas. Characteristics calculated allowed assessing the dynamics and trends of indicators change and determining several challenging directions. An assumption was made that the economic growth due to digitalization faced limitations of infrastructure and technology nature. Common dynamics of the aggregate indicator of the national economy digitalization is positive.

With the purpose to confirm the hypothesis expressed, a regression model of interconnection between the digital economy development and gross domestic product development indicator, and in relation to the number of unemployed people in terms of the existing education, was built. The connection is very strong, which proven by the correlation factor calculation.

The results obtained can be used by the state authorities of federal and regional levels and the methodical fundamentals in making managerial decisions in the part of developing and implementation of strategic planning documents in conditions of digitalization.

Further direction of the study is seen as forming similar models on the regional level with regard to individual features. This will allow revealing the existing reserves and developing the strategy of their use. In addition, it is possible to form models in terms of the sector, that will allow forecasting the number of the unemployed in terms of education and, possibly, professions.
\end{abstract}

Keywords: digitalization, regression analysis, economic growth, unemployment

\section{INTRODUCTION}

The objective process is the penetration of digital technologies not only into economic systems but also into everyday social life. This fact has a considerable impact on all elements of social and economic system. In connection with this subject actuality, it should be noted that it is rather thoroughly studied by modern researchers, representing both national and foreign science.

The «digital economy» concept was formed on the basis of works of the line of foreign scientists that described the information society theory. The example can be the works of M. Porat [1], W. Dizard [2] et al. Among modern researchers, we should specify several publications that, in our opinion, greatly contributed to this direction formation. For example, D. Tapscott [3], describing the digital economy phenomena, emphasized that information and structured knowledge will serve as resources. Founding on them, the society will transform and will shift to the higher level of functioning. However, despite this positive aspect, the assumed negative aspects were also expressed. Among them, there were listed the economic inequity of the countries, potential unemployment growth, an increase of individual criminogenic factors [4].

Work by J. Christensen [5] is dedicated to the study of digital technologies' impact on industry development 
dynamics. As a result, the experience of transformation of conventional directions of companies activity influenced by the competition that is due to the mass implementation of digital technologies has been described.

Special mention should go to the line of scientists who dedicated their studies to separate impacts of the digitalization process and the introduction of innovative technologies on the results of economic systems functioning. For example, issues of accounting information infrastructure development and, in particular, digital network development, in market entities activities, are the subject of papers by T. Mesenbourg [6], L. Fournier [7], E. Zimmermann [8] and author groups composed of H. Groot, J. Poot and M. Smit [9].

It should be mentioned that, besides the economic consequences of digitalization, they are also studied in the field of politics and society. For example, B. Jonson et al. [10], studying the digital economy, forecasts the political consequences of digitalization. Digital economy is characterized by the appearance of new factors of innovative economic development, requiring the determination of its key vectors [11].

In connection with this, state policy in the real sector, based on the development and implementation of digital technologies, should become the beginning of a certain initial platform for the entire economic activity of the country to be built on [12].

Therefore, determination, analysis and timely correction of digitalization characteristics should become a security of successful overcoming of the break in countries' development, and the source of increasing the population life level and quality. The distribution of digital economy technologies increases labor mobility, due to which human resources can move within and between the countries easier [13]. Complex tasks, that were earlier considered as such requiring the unique professional skills, are more and more often replaced by network and digital technologies [14]. This is the way to possible unemployment risks at forming new fields and regression of "obsolete" sectors.

In studies dedicated to the issues of digitalization and employment interconnection, several approaches were formed. Works aimed at workplace creation, as a rule, are positive due to being based on an idea of multiplicative growth based on the creation and development of high tech sectors [15]. However, other authors share the opinion that this process has a negative impact on the population's life level and quality. In particular, not denying the process of creating new workplaces, it is specified for the relative low salary and, respectively, the life quality decrease [16]. It is obvious that the issue of differentiation in labor remuneration and the quality of life is closely connected with the level or workers' qualifications. The widely held belief is that technological changes can cause the growth of short-term unemployment, but their impact on longterm unemployment still remains highly questionable [17].
Therefore, a hypothesis of this study is an assumption of a close relationship between the national economic system's digital development and the result of its functioning, together with the unemployment in terms of education. Educational level of the unemployed was chosen with the purpose to determine the common direction of the change dynamics. An assumption is made that digitalization contributes to the unemployment growth in low-qualified and the decrease of this parameter in high-qualified specialists.

It should be noted that a slightly limited number of papers by Russian authors is dedicated to this subject. In addition, in the number of cases, the studies specified are of the discussion nature. Divisiveness in the part of practical implementation of the results obtained, as a rule, is expressed in the impossibility to receive initial data for the time-testing of methodical developments. It is connected with the use of initial data from closed sources. In addition, rather often the selection of indicators and their scaling are carried out based on the use of expert assessment methods. This method does not always provide the objective result due to its specifics. And the use of foreign approaches is often impossible due to considerable differences in stylistic national bases.

The method developed and time-tested in terms of this study does not eliminate all the disadvantages specified and does not aspire to be the universal and the only correct approach to the economy digitalization. The main differences and advantages in this case are the assessment universal nature and objectivity due to the fact that data from official statistic compilations served as a source. In addition, this approach establishes the functional connection between digitalization and the main economic result at the national level.

\section{METHODS}

A complex digital economy development indicator was formed in this study with the purpose to confirm the hypothesis specified earlier. This process was implemented in a line of stages.

The list of digital development indicators was formed at the first stage. Official statistic compilations serve as a source. This stage is designated to provide the application objectivity and universality. In addition, the possibility of multicultural comparison and analysis of dynamics should be provided. Forming was carried out under five units reflecting several directions: digitalization of entrepreneurial sector organizations; digital state; population in digital state; information and communication technologies sector. The initial list details are given in Table 1. 
Table 1 Initial data by units

\begin{tabular}{|c|c|}
\hline Unit & Indicator \\
\hline $\begin{array}{l}\text { Digitalization } \\
\text { entrepreneurial } \\
\text { organizations }\end{array}$ & $\begin{array}{l}\text { Share of organizations using: } \\
\text { - broadband Internet; } \\
\text { - websites; } \\
\text { - cloud services; } \\
\text { - RFID technologies; } \\
\text { - ERP systems. }\end{array}$ \\
\hline Digital state & 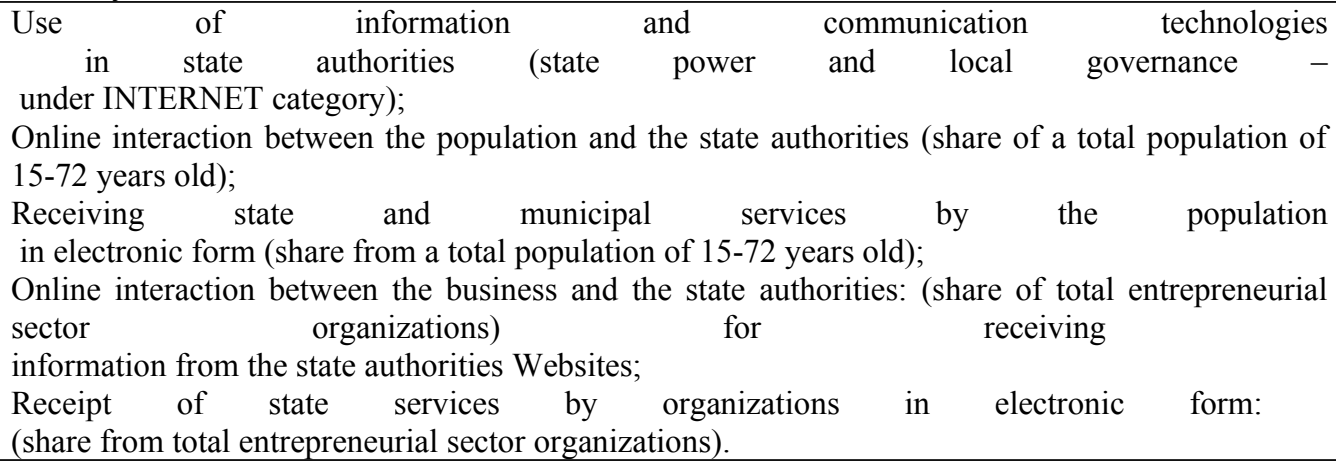 \\
\hline $\begin{array}{l}\text { Population in digital } \\
\text { state }\end{array}$ & $\begin{array}{l}\text { Access to broadband Internet in private households (share from total private households); } \\
\text { Internet use by the population (share from total population of } 15-74 \text { years old) almost every day }\end{array}$ \\
\hline $\begin{array}{l}\text { Information and } \\
\text { communication } \\
\text { technologies sector }\end{array}$ & $\begin{array}{l}\text { Share of innovation goods, work, services in a total volume of shipped } \\
\text { goods, work, services provided } \\
\begin{array}{l}\text { Share of expenses at technology innovations } \\
\text { goods shipped, work, services provided }\end{array}\end{array}$ \\
\hline
\end{tabular}

The second stage is the conversion of all the indicators specified in the nondimensional form. Due to the fact that all indicators provide for the possibility of data representation as a coefficient, this process was carried out by dividing initial values by 100 .
Third stage - formation of a complex indicator under each of the units highlighted. It was made by calculating the mean geometric value. It should be mentioned at this that the equality of all indicators is assumed. Data obtained are given in Table 2.

Table 2 National economy digitalization parameters by units

\begin{tabular}{|l|l|l|l|l|}
\hline \multirow{2}{*}{ Unit } & \multicolumn{3}{|c|}{ Indicator } \\
\cline { 2 - 5 } & \multicolumn{1}{|c|}{2015} & \multicolumn{2}{|c|}{2016} & 2017 \\
\hline $\begin{array}{l}\text { Digitalization of entrepreneurial sector } \\
\text { organizations }\end{array}$ & 0,2245 & 0,2351 & 0,2495 & 0,2782 \\
\hline Digital state & 0,3947 & 0,4789 & 0,5517 & 0,6174 \\
\hline Population in digital state & 0,6067 & 0,6387 & 0,6633 & 0,7097 \\
\hline $\begin{array}{l}\text { Information and communication } \\
\text { technologies sector }\end{array}$ & 0,0483 & 0,0438 & 0,0445 & 0,0506 \\
\hline
\end{tabular}

It should be mentioned that calculating indicators for periods before 2015 and periods after 2018 is unavailable so far due to the absence of data. However, even the limited time interval allows receiving a common notion about this sphere dynamics.
The first stage is forming a complex digital economy development indicator (DEDI) on the national level - this process was carried out by additive indicator folding by units. Data obtained are given in Table 3.

Table 3 Digital economy development indicator

\begin{tabular}{|c|c|c|c|c|}
\hline & 2015 & 2016 & 2017 & 2018 \\
\hline DEDI & 1,2743 & 1,3965 & 1,5090 & 1,6559 \\
\hline
\end{tabular}


The fifth stage is checking the hypothesis on the impact of the national economy digitalization on the result of its functioning, the use of regression analysis. Regression analysis - set os statistical methods of studying the influence of one or several independent variables on the dependent variable. The method specified was selected due its relative simplicity, however, it must be admitted that the time interval analyzed is rather limited. Therefore, only short-term trends can be diagnosed. The value of the Gross Domestic Product (GDP) was accepted as a parameter reflecting the main economic result of national economy functioning.

The check for correlation dependence revealed the strong connection between the DEDI and GDP indicators.
Correlation factor was 0.965 . Regression equation has the following form:

$$
\mathrm{GDP}=9045709.2678+56326252.3964 * \mathrm{DEDI}
$$

This model can be admitted important because it has the following characteristics: adjusted coefficient of determination 0.90 ; p-criterion less than 0.03 .

With the purpose to check interconnection between DEDI and unemployment parameters, regression equations were built in terms of the parameters of the number of unemployed people by education levels: higher, secondary technical, compulsory. The correlation factors obtained, and regression models are given in Table 4.

Table 4 Assessing the interdependence of DEDI and unemployment parameters

\begin{tabular}{|l|c|c|l|}
\hline $\begin{array}{c}\text { Parameter of the number of unemployed } \\
\text { people by education levels }\end{array}$ & Correlation factor & Regression equation & \multicolumn{1}{|c|}{$\begin{array}{c}\text { Regression model } \\
\text { assessment criteria }\end{array}$} \\
\hline Higher $\left(\mathrm{X}_{\text {higher }}\right)$ & $-0,87$ & $\mathrm{X}_{\text {higher }}=0.835-0.387 * \mathrm{DEDI}$ & $\begin{array}{l}\mathrm{R} 2=0,86 \\
\mathrm{p}=0,03\end{array}$ \\
\hline Intermediate vocational education $\left(\mathrm{X}_{\mathrm{iv}}\right)$ & $-0,90$ & $\mathrm{X}_{\mathrm{iv}}=0.673-0.170 * \mathrm{DEDI}$ & $\begin{array}{l}\mathrm{R} 2=0,81 \\
\mathrm{p}=0,04\end{array}$ \\
\hline Main total $\left(\mathrm{X}_{\mathrm{mt}}\right)$ & 0,88 & $\mathrm{X}_{\mathrm{mt}}=-0.206+0.184 * \mathrm{DEDI}$ & $\begin{array}{l}\mathrm{R} 2=0,87 \\
\mathrm{p}=0,03\end{array}$ \\
\hline
\end{tabular}

\section{RESULTS}

By analyzing the results obtained, we receive a possibility to make a number of conclusions. For example, it should be mentioned that indicators under each unit demonstrate the growth dynamics throughout the time interval specified. The changes were represented by:

Digitalization of entrepreneurial sector organizations -

$19.3 \%$;

Digital state $-36.1 \%$;

Population in digital state $-14.5 \%$;

Information and communication technologies sector$4.5 \%$.

However, there is a line of peculiarities under the information and communication technologies sector unit. For example, despite the general growth for the period of 2015-2018, a decrease occurs in 2016 with the subsequent growth. This circumstance is caused by the decrease of the share of expenses at technological innovations in general volume

goods shipped, work, services provided.

DEDI common indicator demonstrates a rather considerable and stable growth of around $30 \%$ with the average growth rate of $9.1 \%$.

In assessing the interdependence od DEDI and unemployment parameters, the existence of the strong connection between these indicators should be noted. This conclusion is made based on the calculated correlation coefficients stay are located in the range of 0.9-1.00 under the module.

\section{DISCUSSION}

The results obtained, in the form of the formed regression model, confirm the earlier expressed hypothesis on the interconnection between the digitalization processes and the main result of economic functioning at the nationwide level. It should be mentioned that units highlighted demonstrate different change rates but the common vector is similar and positive. The highest growth is observed in the «digital state» indicator, which is connected with the growth in the interconnection between the authorities of state and local power both with the entrepreneurial sector and with the population through the use of digital and network technologies. The average change under the unit indicators changed was $7.7 \%$. The only indicator that inhibited its growth is the use of Internet by state authorities. The least growth is observed in the «information and communication technologies sector» unit. This fact is connected with the decrease of the specific weight of expenses at technology innovations in the total volume of goods shipped, work, services provided. This decrease is rather considerable and is approximately $20 \%$. This negative trend is smoothed over the unit by the growth of specific weight of innovative goods, work, services in total volume of shipped goods, work, services provided. This growth was approximately $40 \%$. Therefore, we can assume the inhibition of innovation development in further periods due to the decease in this sector financing in the current period. DEDI units, assessing the entrepreneurial sector and the population digitalization, demonstrated average growth rates equaling to $19.1 \%$ and $14.5 \%$, respectively. 
For example, the entrepreneurial sector demonstrated the highest growth in the application of cloud technologies (gain of $47 \%$ ) and ERP systems (gain of $41 \%$ ). The lowest gain is the broadband Internet use gain $(+8.1 \%)$, which is, possibly, connected with infrastructure and technological limitations. Population digitalization also demonstrated growth under all indicators; e.g., broadband Internet use grew by $9.6 \%$, and network intensity use grew almost by $25 \%$.

The DEDI growth reserves are seen in increasing the use of digital and network technologies by the entrepreneurial sector and the development of the information and communication technologies sector for elimination of infrastructure and technological limitations of the national economy digitalization growth.

Assessing the interdependence of DEDI and unemployment parameters, we should specify several facts. First, the dependence between these indicators can be considered proven. Second, digitalization is directly related to the number of low-qualified unemployed people (with mandatory education) and is inversely related to the number of those high-qualified (with higher education) and medium-qualified (with intermediate vocational education).

Therefore, it can be assumed that the further digitalization of the national economy will contribute to the growth of unemployment in the unskilled labor. This can be explained by the absence of the required skills of adaptation to changing conditions.

\section{CONCLUSION}

In summarizing this study, we should note that the national economy digitalization is the objective process. Despite the considerable number of papers dedicated to this issue theoretical aspect, the single approach to assessing the digitalization level and the analysis of its interconnection with the result of social and economic systems functioning. A slightly limited number of papers by Russian authors is dedicated to this subject. The practical application of the results obtained is complicated due to the line of objective factors.

The methodic approach offered is universal. The constructed regression model confirms the formulated hypothesis and allows assessing the functional relation between the digitalization and the main result of economic functioning at the nationwide level.

All units analyzed demonstrate positive dynamics. However, changing rates differ. Due to the fact that the highest growth under the "digital state» unit, the least change under the «information and communication technologies sector» unit, DEDI units, assessing the digitalization of the entrepreneurial sector and population, demonstrated average growth rates of $19.1 \%$ and $14.5 \%$ respectively. It should be mentioned that the internal dynamics of indicators is uneven; separate limitations and growth reserves exist.
It should also be mentioned that the impact of DEDI on unemployment is the objective fact. Respectively, for decreasing this negative impact, it is required to intensify activity in the field of further training, and personnel development. This will allow decreasing the negative impact.

The results obtained can be used by the state authorities of federal and regional levels and the methodical fundamentals in making managerial decisions in the part of developing and implementation of strategic planning documents in conditions of digitalization.

Further direction of the study is seen as forming similar models on the regional level with regard to individual features. This will allow revealing the existing reserves and developing the strategy of their use. In addition, it is possible to form models in terms of the sector, that will allow forecasting the number of the unemployed in terms of education and, possibly, professions.

\section{REFERENCES}

[1] M. Porat, The Information Economy: Definition and Measurement, Washington, DC: United States Department of Commerce, 1977. $250 \mathrm{p}$

[2] W. Dizard, The Coming Information Age: An Overview of Technology, Economics, and Politics, New York: Longman, 1989. $250 \mathrm{p}$.

[3] D. Tapscott, The Digital Economy: Promise and Peril in the Age of Networked Intelligence, New York: McGraw-Hill, 1997. 288 p.

[4] D. Coyle, The Weightless World: Strategies for Managing the Digital Economy, MIT Press, 1999. 250 p.

[5] J. Christensen, The Industrial dynamics of the new digital economy, Edward Elgar Publishing Ltd, 2003. $271 \mathrm{p}$.

[6] T.L. Mesenbourg, Measuring the Digital Economy. U.S. Bureau of the Census. URL: http:// www.census.gov/content/dam/Census/library/workingpapers/2001/econ/digitalecon.pdf (referral date: 03.04.2019).

[7] L. Fournier, Merchant Sharing. Cornell University Library arXiv:1405.2051. URL: https:// arxiv.org/pdf/1405.2051 (03.04.2019).

[8] E.W. Zimmermann, What We Mean by Resources, Chapter 1, Texas Looks Ahead, Drummond L.Texas: ed., Austin, 1944. 136 p.

[9] H. De Groot, J. Poot, M. Smit, Agglomeration externalities, innovation and regional growth: 
theoretical perspectives and meta-analysis, Capello R. (Ed), Handbook of Regional Growth and Development Theories. Cheltenham: Edward Elgar Publishing Limited, 2009. 529 p. pp. 256-281.

[10] B. Johansson, The Emerging Digital Economy: Entrepreneurship, Clusters, and Policy (Advances in Spatial Science), Berlin, Heidelberg: Springer, 2006. $352 \mathrm{p}$.

[11] S.A. Dyatlov, O.S. Lobanova, V. Chzhou, Upravleniye regional'nym informatsionnym prostranstvom v usloviyakh tsifrovoy ekonomiki, Ekonomika regiona. 2018. T.14, vyp. 4. S. 1194-1206.

[12] O.A. Romanova, Prioritety promyshlennoy politiki Rossii v kontekste vyzovov promyshlennoy revolyutsii. Chast' 1, Ekonomika regiona. T.14. vyp. 2 (2018), S. 420-432.

[13] R. Baldwin, The Great Convergence: Information Technology and the New Globalization. The Belknap Press of Harvard University Press, Cambridge, MA, 2016.

[14] A. McAfee, E. Brynjolfsson, Machine, Platform, Crowd: Harnessing our Digital Future. W. W. Norton \& Company, New York, 2017.

[15] E. Moretti, P. Thulin, Local multipliers and human capital in the united states and Sweden, Industrial and Corporate Change Volume 22, Issue 1, February 2013, pp. 339-362

[16] R. Florida, The New Urban Crisis: Gentrification, Housing Bubbles, Growing Inequality, and What We Can Do About It Basic Books, New York, 2017.

[17] Martha Garcia-Murilloa, Ian MacInnesb, Johannes M. Bauerc Techno-unemployment: A framework for assessing the effects of information and communication technologies on work, Telematics and Informatics Volume 35, Issue 7, October 2018, pp. 1863-1876 https://doi.org/10.1016/j.tele.2018.05.013

[18] Tsifrovaya ekonomika: kratkiy statisticheskiy sbornik, G.I. Abdrakhmanova, L.M. Gokhberg, A.V. Dem'yanova i dr.; Nats. issled. un-t «Vysshaya shkola ekonomiki». M.: NIU VSHE, 2018. 96 s. 250 ekz. ISBN 978-5-7598-1743-7.

[19] Tsifrovaya ekonomika: 2019: kratkiy statisticheskiy sbornik, G.I. Abdrakhmanova, K.O. Vishnevskiy, L.M. Gokhberg i dr.; Nats. issled. un-t «Vysshaya shkola ekonomiki». M.: NIU VSHE, 2019. 96 s. 250 ekz. ISBN 978-5-7598-1927-1
[20] Tsifrovaya ekonomika: 2020: kratkiy statisticheskiy sbornik, G.I. Abdrakhmanova, K.O. Vishnevskiy, L.M. Gokhberg i dr.; Nats. issled. un-t «Vysshaya shkola ekonomiki». M.: NIU VSHE, 2020. 112 s. 300 ekz. ISBN 978-5-7598-2148-9 